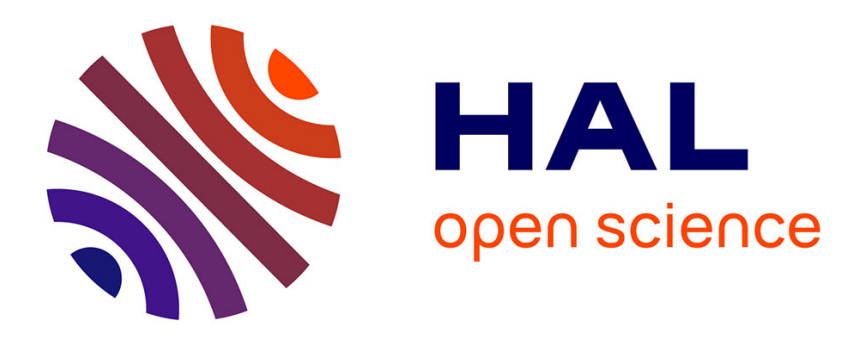

\title{
Biogeochemical cycling in the Strait of Georgia
}

\author{
S.C. Johannessen, R.W. Macdonald, B. Burd, A. van Roodselaar
}

\section{To cite this version:}

S.C. Johannessen, R.W. Macdonald, B. Burd, A. van Roodselaar. Biogeochemical cycling in the Strait of Georgia. Marine Environmental Research, 2008, 66, 10.1016/j.marenvres.2008.10.001 . hal00563059

\section{HAL Id: hal-00563059 \\ https://hal.science/hal-00563059}

Submitted on 4 Feb 2011

HAL is a multi-disciplinary open access archive for the deposit and dissemination of scientific research documents, whether they are published or not. The documents may come from teaching and research institutions in France or abroad, or from public or private research centers.
L'archive ouverte pluridisciplinaire HAL, est destinée au dépôt et à la diffusion de documents scientifiques de niveau recherche, publiés ou non, émanant des établissements d'enseignement et de recherche français ou étrangers, des laboratoires publics ou privés. 


\section{Accepted Manuscript}

Biogeochemical cycling in the Strait of Georgia

S.C. Johannessen, R.W. Macdonald, B. Burd, A. van Roodselaar

PII:

S0141-1136(08)00216-X

DOI:

10.1016/j.marenvres.2008.10.001

Reference:

MERE 3292

To appear in:

Marine Environmental Research

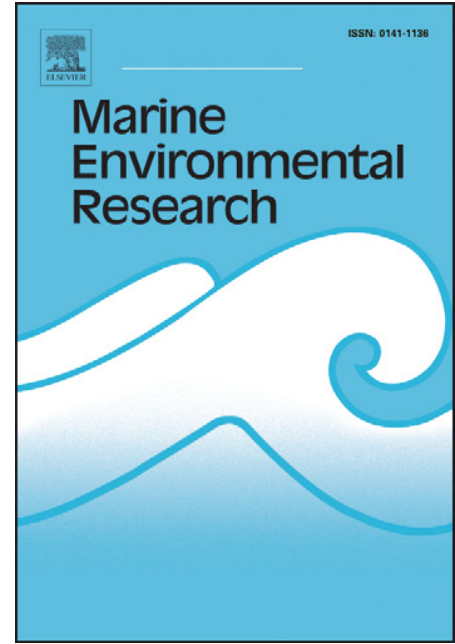

Please cite this article as: Johannessen, S.C., Macdonald, R.W., Burd, B., van Roodselaar, A., Biogeochemical cycling in the Strait of Georgia, Marine Environmental Research (2008), doi: 10.1016/j.marenvres.2008.10.001

This is a PDF file of an unedited manuscript that has been accepted for publication. As a service to our customers we are providing this early version of the manuscript. The manuscript will undergo copyediting, typesetting, and review of the resulting proof before it is published in its final form. Please note that during the production process errors may be discovered which could affect the content, and all legal disclaimers that apply to the journal pertain. 


\section{ACCEPTED MANUSCRIPT}

\section{Biogeochemical cycling in the Strait of Georgia - Special Issue}

S. C. Johannessen, R. W. Macdonald, B. Burd and A. van Roodselaar

The encroachment of human activities on coastal waters is a worldwide problem (GESAMP, 1990) that requires site-specific consideration of how multiple discharges from of land-based sources affect marine systems. Appropriate policy to protect marine resources requires, among other things, scientific data to understand the functioning of coastal waters (e.g., baselines, residence times, sinks, pathways) and the means to detect and quantify the impacts of using the coastal ocean as a direct or indirect means to dispose of waste. The papers in this special issue present interpretations of scientific observations carried out during a five-year project undertaken in the Strait of Georgia, British Columbia, Canada (Figure 1) as a collaboration among Fisheries and Oceans Canada, Natural Resources Canada and Metro Vancouver (formerly the Greater Vancouver Regional District). The objectives of the project were to provide context for local monitoring of discharges into the Strait of Georgia from Metro Vancouver's wastewater outfalls, and also to enhance confidence in the scientific findings through the process of peer-review conducted during publication of results in international journals. Furthermore, the project provided the means to advance our understanding of underlying sedimentological, geochemical and benthic processes taking place in the Strait of Georgia. Four of the papers presented here address directly the effects of the wastewater on the local environment, while other papers provide overviews of the ambient sedimentological and geochemical conditions and the benthic biota and sponge reefs of the greater Strait of Georgia. 
Natural sediment transport and deposition in the Strait of Georgia, which are complex, form a crucial background process onto which municipal outfall particulates load. Riverborne sand and coarse silt are deposited on the Fraser River delta, from where they are moved northward along the bottom by the asymmetrical tidal currents. The finer material remains longer in the surface plume before it is deposited and, in some parts of the Strait, becomes extensively reworked. Hill et al. (this issue) combine data from sedimentological, multibeam mapping and seismic profiling studies to give a comprehensive description of local sediment dispersal.

Fraser River discharge dominates the particulate and dissolved organic carbon that enter the Strait of Georgia system, but organic carbon is also produced in situ by primary production (Johannessen, 2003). Quarterly measurements throughout the Strait of Georgia and Haro and Juan de Fuca Straits show that, compared with the Fraser River and marine primary production, very little organic carbon enters the Strait of Georgia with the inflowing seawater (Johannessen et al, this issue b). The Strait is dynamic with respect to organic carbon, with an annual flux through the system of approximately twice the standing inventory.

The organic carbon supports an active benthic community. Burd et al. (this issue a) provide an extensive review of the benthic biota and their habitat in the Strait of Georgia, based on data collected over more than 20 years. The review links the organisms with the sediment conditions that surround them, illustrating the importance of sediment 


\section{ACCEPTED MANUSCRIPT}

geochemistry and sedimentation to an understanding of benthic biomass and community structure.

Benthic biota in the immediate area of the Iona Island municipal wastewater outfall show effects of the effluent. The total benthic biomass is depleted, and the population is dominated more by polychaetes and less by bivalves and ophiuroids, relative to other parts of the Strait (Burd et al., this issue b). Biomass at sites close to anthropogenic discharges, such as municipal outfalls, pulp mills and the abandoned Britannia copper mine, is not predicted by the organic flux - biomass relationship that describes more remote sites. In addition to local organic flux, biomass and other biological characteristics are affected by the quality and source of organic matter (lability) and by the contribution of terrigenous material.

While benthic macrofauna appear to thrive under conditions of high river discharge, the abundance of reef-forming, siliceous hexactinellid sponges is low under the Fraser River plume, where the sedimentation rate is high (Cook et al., this issue). The sponges do survive there, apparently physically adapted to the turbidity, if not in great numbers. The biggest threat to these sponge reefs and their associated fauna appears to be mechanical trawling, which breaks the fragile sponges, destroying both the sponges and the habitat for rockfish and other animals that was formerly provided by the sponges.

The signature of the municipal outfall can be seen in a sediment core collected within 0.5 $\mathrm{km}$ of the Iona outfall in enhanced organic carbon oxidation and fluxes of elements like 


\section{ACCEPTED MANUSCRIPT}

$\mathrm{Cd}, \mathrm{Ag}$ and $\mathrm{U}$, which are sensitive to redox conditions in sediments. Other redox elements like Mn, Re, Mo, total sulphur or acid-volatile sulphides, provide little indication of significant oxygen depletion due to the addition of labile organic carbon from wastewater (Macdonald et al., this issue). Within the Greater Strait of Georgia there is a wide range of natural variability in redox marker distributions and fluxes due to large natural variations in organic flux, making it difficult to find any significant impact from organic loadings from outfalls.

Although there is no evidence of significant oxygen depletion in the sediments near the Iona Island wastewater outfall, over a finer spatial scale, a somewhat lower oxygen concentration around the outfall appears to recorded in iron oxide or hydroxyl-oxide staining on the shells of the infaunal bivalve Axinopsida serricata (Burd et al., $2008 \mathrm{c}$ ). This staining, which depends on the reduction of iron to soluble forms that diffuse and reprecipitate, may provide a simple means to conduct preliminary surveys of organic loadings around point sources like marine outfalls.

Polybrominated diphenyl ethers (PBDEs), principally used as flame retardants, are a concern, as their use and emissions to the environment have been growing rapidly (de Wit, 2002). These contaminants, which are commonly found in households and businesses, and readily "go down the drain" in cleaning water, mean that municipal wastewater provides a major pathway for PBDEs into the environment generally (Chapman, 2006) and into the Strait of Georgia in particular (Johannessen et al., this issue a). Because PBDEs have been introduced into wide-scale use relatively recently, 


\section{ACCEPTED MANUSCRIPT}

they are now found in highest concentration around current points of entry, including the Iona Island outfall. Polychlorinated biphenyls (PCBs), conversely, no longer have a local source because they have been banned in North America for about thirty years, and their concentration in sediments is primarily controlled by the continuing flux of PCB into coastal waters from revolatilization of contaminated soil reservoirs, and by sedimentation and mixing rates in surface sediments. Sediment core profiles from the Strait of Georgia show that while PCB concentrations continue to decrease slowly, PBDEs are presently increasing rapidly.

Collectively, these papers demonstrate that the fate of particles, organic carbon and contaminants discharged into the coastal ocean, and the response of benthic biota, depend not only on the contaminants themselves but also on the nature of the receiving environment. A low sedimentation rate in the northern Strait of Georgia, combined with benthic mixing, for example, produces high concentrations of PCBs in surface sediments that have little to do with local pollution. The sedimentation rates themselves are controlled by a complex combination of fluvial discharge, tidal currents, and underwater slope stability. And the biota associated with reef-forming sponges are limited by turbidity near the Fraser River plume, while benthic infauna thrive near the river. This complexity requires that management decisions concerning the Strait of Georgia be informed not only by the nature of a particular stressor but also by an understanding of the dynamics and cycling of particles, organic matter and benthic communities in the Strait. 


\section{ACCEPTED MANUSCRIPT}

\section{References}

Burd, B., Barnes, P. A., Wright, C. A., Thomson, R. E. 2008. A review of subtidal benthic habitats and invertebrate biota of the Strait of Georgia, British Columbia. Marine Environmental Research, this issue.

Burd, B., Macdonald, R. W., Johannessen, S. C., van Roodselaar, A. 2008. Responses of subtidal benthos of the Strait of Georgia to ambient sediment conditions and natural and anthropogenic deposition. Marine Environmental Research, this issue.

Burd, B., Macdonald, R. W., van Roodselaar, A., Wright, C. A. 2008. Axinopsida serricata shell encrustation: A potential indicator of organic enrichment conditions in sediments in the southern Strait of Georgia, British Columbia, Canada. Marine Environmental Research, this issue.

Chapman, P.M. 2006. Emerging substances - emerging problems? Environmental Toxicology and Chemistry, 25(6): 1445-1447.

Cook, S. E., Conway, K. W., Burd, B. 2008. Status of the glass sponge reefs in the Georgia Basin. Marine Environmental Research, this issue.

de Wit, C.A. 2002. An overview of brominated flame retardants in the environment. Chemosphere, 46: 583-624.

GESAMP 1990. The State of the Marine Environment. UNEP Regional Sea Reports and Studies. No. 115. UNEP Blackwell Scentific Publications: Oxford, UK.

Hill, P. R., Conway, K. W., Lintern, D. G., Meulé, S., Picard, K., Barrie, J. V. 2008. Sedimentary Processes and Sediment Dispersal in the southern Strait of Georgia, BC, Canada. Marine Environmental Research, this issue. 
Johannessen, S.C., Macdonald, R. W., Paton, D. W. 2003. A sediment and organic carbon budget for the greater Strait of Georgia. Estuarine, Coastal and Shelf Science, 56(3-4): 845-860.

Johannessen, S. C., Macdonald, R. W., Wright, C. A., Burd, B., Shaw, D. P., van Roodselaar, A. 2008. Joined by geochemistry, divided by history: PCBs and PBDEs in Strait of Georgia sediments. Marine Environmental Research, this issue.

Johannessen, S. C., Potentier, G., Wright, C. A., Masson, D., Macdonald, R. W. 2008. Water column organic carbon in a Pacific Marginal sea (Strait of Georgia, Canada). Marine Environmental Research, this issue.

Macdonald, R. W., Johannessen, S. C., Gobeil, C., Wright, C. A., Burd, B., van Roodselaar, A. 2008. Sediment redox tracers in Strait of Georgia sediments - can they inform us of the loadings of organic carbon from municipal wastewater? Marine Environmental Research, this issue. 


\section{ACCEPTED MANUSCRIPT}

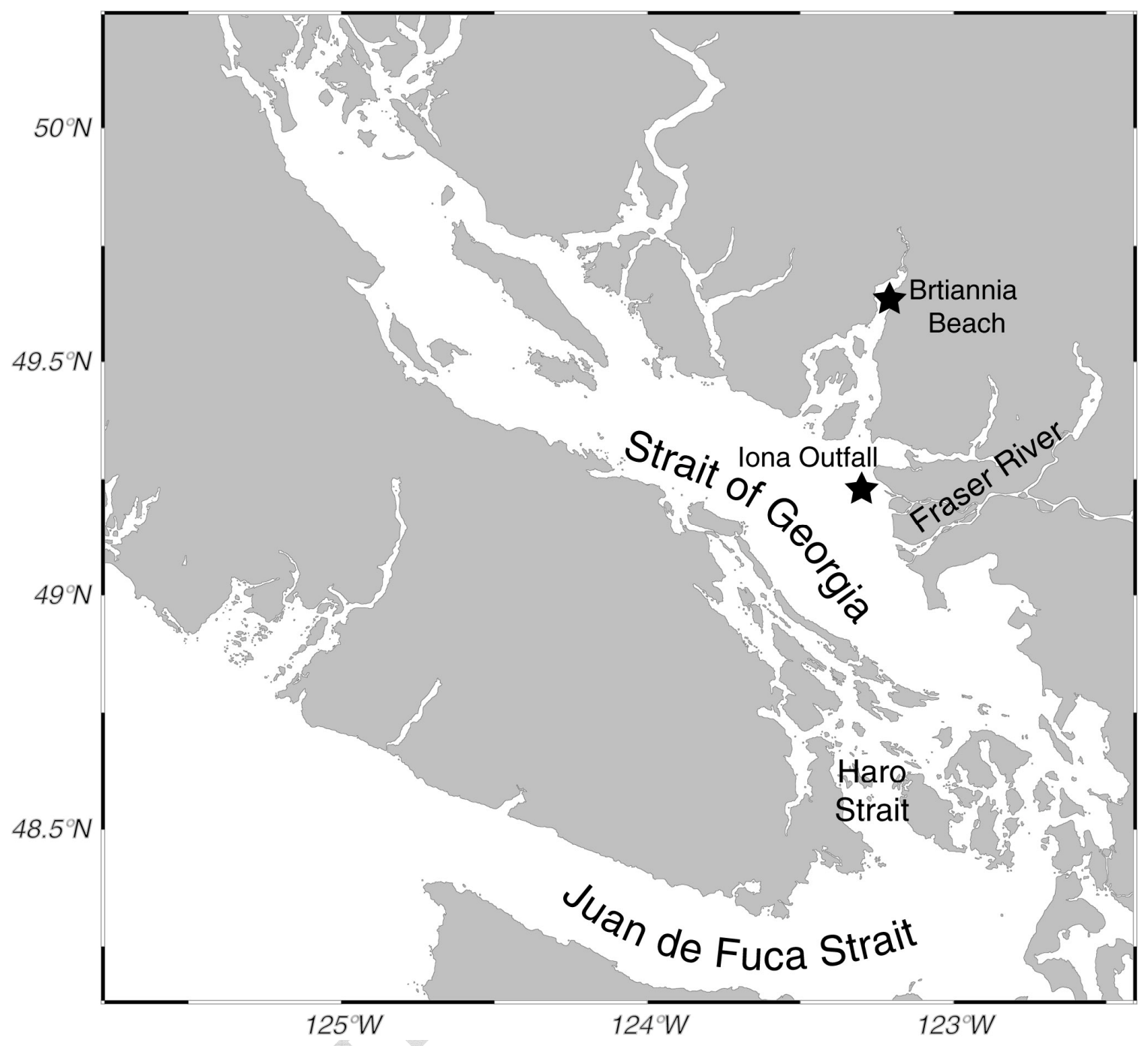

